\title{
Introduction of emergency contraceptive pills in the public health system of Pakistan: A south-to-south collaboration
}

\author{
M.E. Khan \\ Population Council \\ Gul Rashida \\ Population Council \\ Sharif M.I. Hossain \\ Population Council \\ Ali M. Mir \\ Population Council \\ Ubaidur Rob \\ Population Council
}

Follow this and additional works at: https://knowledgecommons.popcouncil.org/departments_sbsr-rh

Part of the Demography, Population, and Ecology Commons, International Public Health Commons, and the Public Health Education and Promotion Commons How does access to this work benefit you? Let us know!

\section{Recommended Citation}

Khan, M.E., Gul Rashida, Sharif M.I. Hossain, Ali M. Mir, and Ubaidur Rob. 2008. "Introduction of emergency contraceptive pills in the public health system of Pakistan: A south-to-south collaboration," FRONTIERS Final Report. Washington, DC: Population Council. 


\section{Introduction of Emergency Contraceptive Pills in the Public Health System of Pakistan: A South-to-South Collaboration}

Frontiers in Reproductive Health, Population Council

M.E. Khan

Gul Rashida Shaikh

Sharif M I Hossain

Ali Mohammad Mir

Ubaidur Rob

May 2008

This project was made possible by the generous support of the American people through the United States Agency for International Development (USAID) under Cooperative Agreement Number HRN-A-00-98-00012-00 and In-house Project No. 8015.53123. The contents are the responsibility of the FRONTIERS Program and do not necessarily reflect the views of USAID or the United States Government.
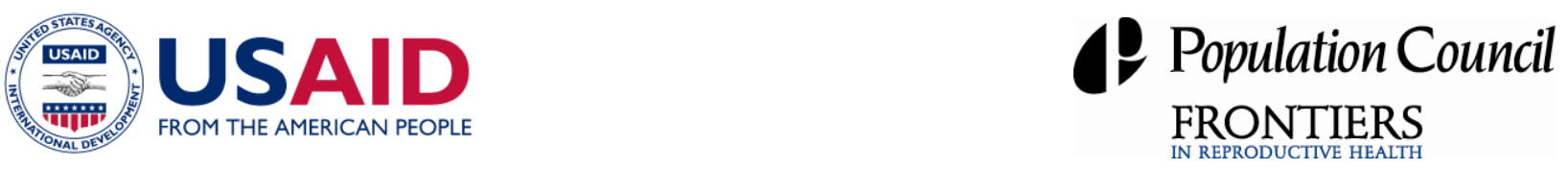


\section{EXECUTIVE SUMMARY}

This report describes a south-to-south collaboration to assist the Ministry of Health of Pakistan to introduce emergency contraception (EC) into its family planning program, supported by the Population Council's USAID-funded Frontiers in Reproductive Health (FRONTIERS) program. The collaboration consisted of a three-day visit by senior managers from the Pakistani health authorities to Bangladesh to familiarize them with the EC program in that country, followed by a two-day consultative meeting in Islamabad, Pakistan to draw up concrete plans for introduction of the method into the Pakistan system. The consultation was attended by local stakeholders, regional experts from countries in South Asia with experience of introducing EC (Nepal, Bangladesh and India), and by Population Council staff.

Participants at the consultation developed plans to introduce EC into both community-based distribution and clinical programs. The plans included staff training, commodity logistics, and development of Information, Education and Communication Materials, many of which will be adapted from materials used in other EC projects in the region supported by FRONTIERS. The Minister of Health personally pledged the ministry's support for the effort and UNFPA agreed to support the procurement of the EC commodities. The method will first be introduced in the twenty districts covered by the USAID-funded Family Advancement for Life and Health (FALAH) project, which is implemented by a consortium led by the Population Council.

The activity successfully met its goals. Providing South to South technical assistance was demonstrated to be an effective strategy for introducing sensitive services and is recommended for other regions and similar services. 


\section{TABLE OF CONTENTS}

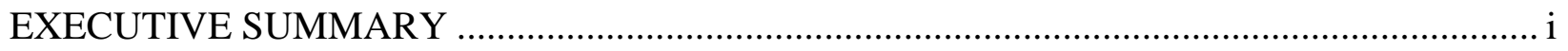

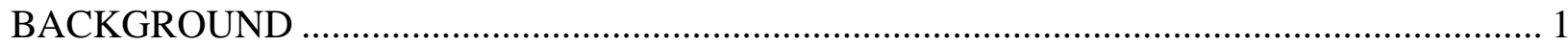

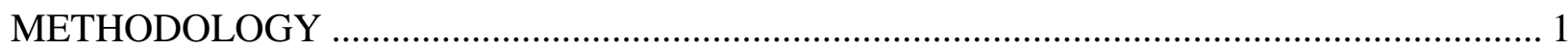

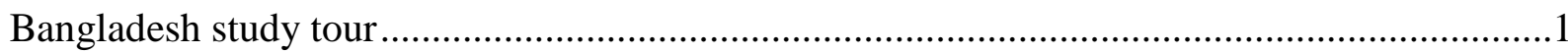

Two-day Consultative Meeting on Emergency Contraception, Islamabad, Pakistan,

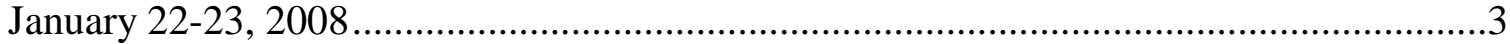

OUTCOME OF THE SOUTH TO SOUTH COLLABORATION .............................................. 4

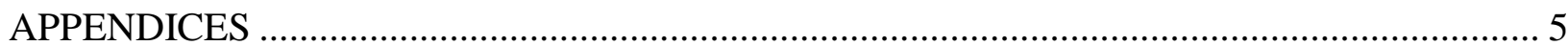

Appendix 1: List of Officials who Visited Bangladesh ..............Error! Bookmark not defined. Appendix 2a: Agenda of Study Tour to Bangladesh to Observe ECP Program Activities ..........5

Appendix 2b: List of Selected Participants in the ECP Seminar ..................................................6

Appendix 2c: Agenda of Two-day National Consultative Seminar on Emergency

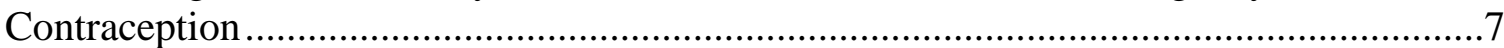

Appendix 2d: Details of Presentations Made during Group Work ............................................. 


\section{BACKGROUND}

Currently, in Pakistan, emergency contraception (EC) pills are available through the Ministry of Population Welfare (MOPW) and the Greenstar Social Marketing program. However, it has not yet become available to the population that is served by the Ministry of Health (MOH). The MOH would like to include EC in its National Plan for Family Planning and Primary Health Care, but does not, however, have extensive experience with EC.

The Population Council's USAID-funded Frontiers in Reproductive Health (FRONTIERS) program has successfully supported the introduction of EC in India, Nepal and Bangladesh. To help the MOH introduce EC in Pakistan, staff from FRONTIERS and the Population Council's Pakistan office developed and organized a two-phase south-to-south collaboration to initiate the process of introducing the method within the MOH's program nationwide.

\section{METHODOLOGY}

The collaboration consisted of two activities:

- A five-day tour by eight senior program managers from the Pakistan Ministries of Population Welfare and of Health to visit the EC program of Bangladesh.

- A two-day consultative meeting in Islamabad at which national stakeholders and expert counterparts from Bangladesh, India, and Nepal worked together to develop a plan for introducing EC within the Pakistan $\mathrm{MOH}$.

\section{Bangladesh study tour}

A team of six officials of the MOH and MOPW visited Bangladesh during December 2-6, 2007. The purpose was to study the EC program in Bangladesh and become familiar with the processes involved in its introduction and integration within the National Family Planning Program. The group met with public sector and NGO managers. The Agenda of the study tour is in Appendix 1.

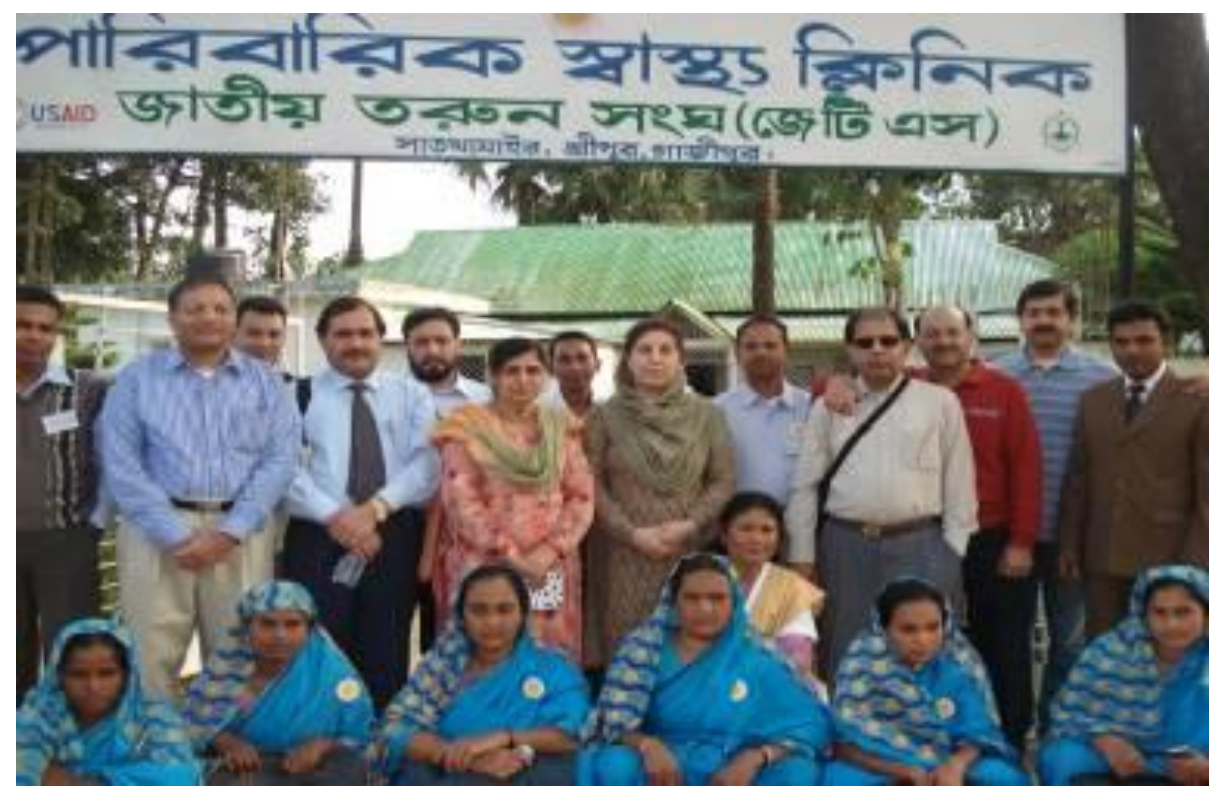


The team consisted of:

1. Dr. Mumtaz Eskar, Director General Technical, Ministry of Population Welfare, Government of Pakistan;

2. Dr. Assad Hafeez, National Coordinator, National Program of Family Planning and Primary Health Care, Ministry of Health, Government of Pakistan;

3. Dr. Malik Safi, Deputy National Coordinator, National Program of Family Planning and Primary Health Care, Ministry of Health, Government of Pakistan;

4. Dr. Tanweer Ahmed, Provincial Coordinator, Punjab, National Program of Family Planning and Primary Health Care, Ministry of Health, Government of Pakistan;

5. Dr. Inam Ullah Khan, Provincial Coordinator, NWFP, National Program of Family Planning and Primary Health Care, Ministry of Health, Government of Pakistan;

6. Dr. Saleem Abroo, Provincial Coordinator, Baluchistan, National Program of Family Planning and Primary Health Care, Ministry of Health, Government of Pakistan;

The team was accompanied by Dr. Ali Mohammad Mir, Director Programs, and Dr. Gul Rashida Shaikh, Director, HR and Training, both at the Population Council, Pakistan.

On the first day of the tour, the team received three presentations from Population Council staff based in Bangladesh that had been involved in the introduction and roll-out of EC:

- Health and population services in Bangladesh: An overview

- Introduction to emergency contraception

- Introducing ECP in family planning programs: Lessons Learned.

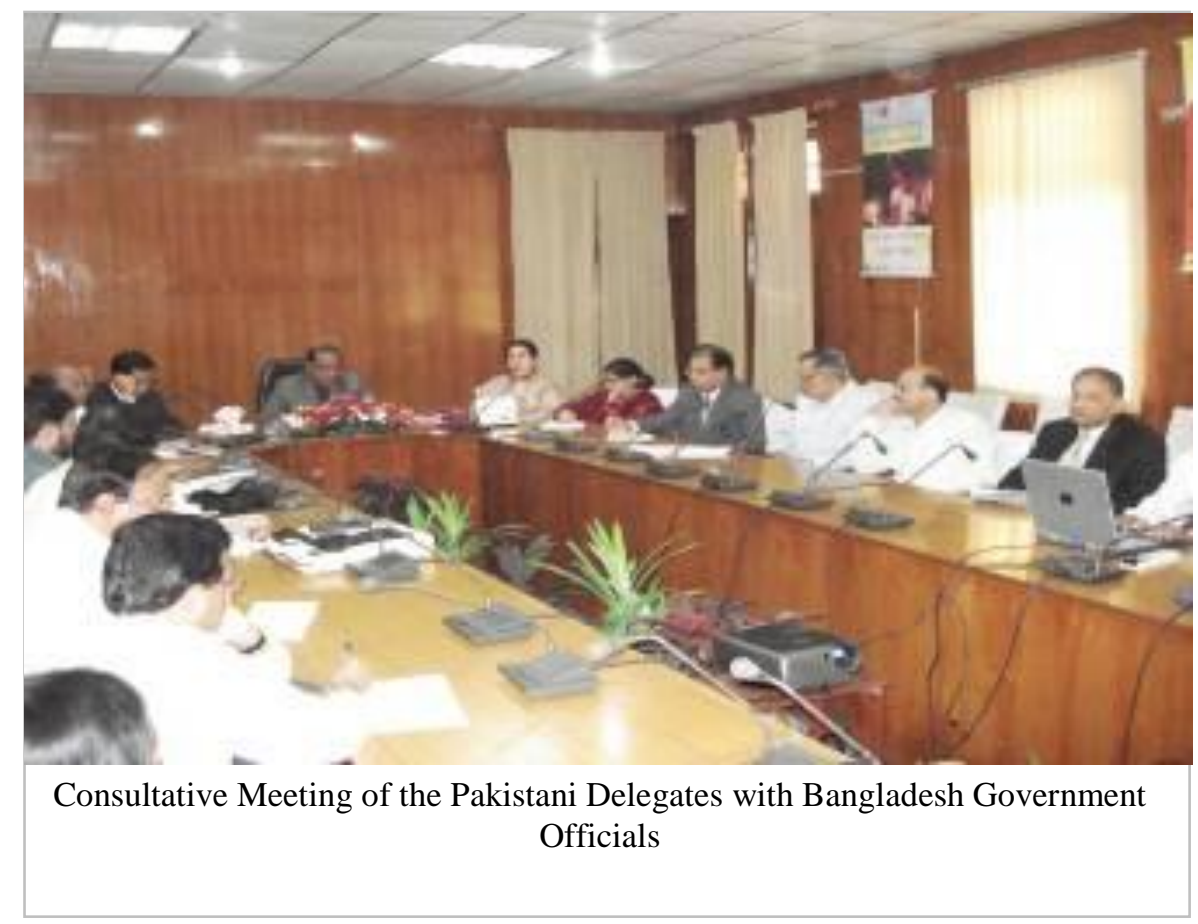

The first presentation gave an overview of the structure of the health and family planning program in Bangladesh. The second presentation was on the EC technology itself, including indications and contraindications, formulations, mode of action, effectiveness, side-effects, etc. The third focused on the processes followed when introducing and scaling up EC in Bangladesh. 
During the remaining two days, the visitors met several high ranking government officials, including the Secretary of Health and Family Welfare. Eight NGO program managers shared their experiences with EC introduction. Finally, the visitors made field visits to clinics to see the EC program in operation. On the last day of the tour, the visitors drafted an agenda for the consultative meeting that the MOPW and Population Council would organize in Islamabad.

\section{Consultative Meeting on Emergency Contraception in Pakistan}

After the study tour to Bangladesh, the Population Council office in Islamabad, in collaboration with the Ministry of Population Welfare, the Ministry of Health and the United States Agency for International Development (USAID), arranged a two-day consultative seminar on EC in Islamabad in January 2008. National and international experts, policymakers, religious scholars and health managers participated with the objectives of:

a. Discussing the availability of EC in Pakistan;

b. Presenting experiences of introducing EC from India, Nepal and Bangladesh;

c. Producing a plan for introducing $\mathrm{EC}$ within the $\mathrm{MOH}$.

A list of participants is given in Appendix 2 and the agenda is in Appendix 3. The seminar consisted of four sessions. In the first two sessions, officials of the MOH, MOPW and representatives from USAID, UNFPA, the Greenstar Social Marketing program and the Population Council presented varied experiences and viewpoints on EC and its incorporation into a national health system. Topics included:

1. An EC contraceptive technology presentation, similar to that made in Bangladesh. Evidence that EC was not an abortifacient was important to health officials concerned about possible negative reactions from religious leaders.

2. FRONTIERS staff made a presentation on the process of introducing EC in Bangladesh. Emphasizing:

- Use of a phased approach for introduction

- Media and communication strategies

- Levels of EC use achieved.

The third presentation described lessons learned from introducing and scaling up EC in India, Nepal, and Bangladesh. Some issues discussed included:

- The need to provide long-term technical assistance to introduce the method

- The evidence that women do not use EC repeatedly

- Prophylactic distribution of EC is the preferred service delivery option.

A discussion of the status of EC in Pakistan formed the fourth session, which indicated it is currently available through the Greenstar Social Marketing project, which has a 76 percent market share of the product, and from the MOPW. The discussion underlined the importance of expanding the availability of EC through channels such as the MOH system. 
Following the panel, participants formed two working groups to discuss ways in which EC could be provided through the $\mathrm{MOH}$ community based providers and $\mathrm{MOH}$ clinics. It was recommended that all community health workers and their supervisors be trained to provide the method and that EC be made available free of charge. UNFPA made a commitment to supply commodities, which made it possible to decide to begin introduction of EC in a limited number of districts. Training and educational materials are to be provided by the Population Council's FRONTIERS program and translated into Urdu and other local languages in Pakistan.

The main recommendations of the consultation were:

- EC is an effective reproductive health service and all steps necessary should be taken to include it in the $\mathrm{MOH}$ systems, both in static health facilities and through community level workers.

- The MOPW and Greenstar are already providing EC at their facilities. They should try to strengthen the program to reach more clients.

- The program should be implemented in a phased manner in selected districts in the fixed facilities for FP \& PHC

- A timeline should be shared with stakeholders for preparing a comprehensive proposal, technical evaluation, implementation and review to be completed in the next one year.

- Linkages should be formalized with stakeholders including MOH, MOPW and other partners for further strengthening the program.

The Honorable Minister of Health for Pakistan chaired the final session. He promised to implement the method within the $\mathrm{MOH}$ and urged his staff to treat EC introduction as a priority. He also declared that resources would not be a constraint in the introduction of EC, and if necessary he would request a re-appropriation of the existing budget to include resources required for the program.

\section{OUTCOME OF THE SOUTH TO SOUTH COLLABORATION}

1. The initiative helped Pakistan understand how other countries introduced and scaled up EC and how lessons from Bangladesh, India and Nepal could be applied in Pakistan.

2. The seminar provided a platform for regional experts to help Pakistan develop an emergency contraception introduction plan.

3. Implementation plans with timelines for introducing EC through community health workers and through health clinics were developed.

In April 2008, the MOH began the introduction of EC in twenty health districts served by the USAID-funded Family Advancement for Life and Health (FALAH) project, implemented by the Population Council. Materials developed for the other South Asian countries arrived and were translated into Urdu and Sind. The experience shows that South to South collaboration can be an effective way to introduce new and underutilized family planning methods in South Asia, and probably other regions as well. 


\section{APPENDICES}

\section{Appendix 1: Agenda of Study Tour to Bangladesh to Observe ECP Program Activities}

December 2-6, 2007

\begin{tabular}{|c|c|c|}
\hline \multirow{3}{*}{$\begin{array}{l}\text { Date } \\
02.12 .07 \\
\text { Sunday }\end{array}$} & Time & Program \\
\hline & $\begin{array}{l}0215 \text { hrs. } \\
0400 \text { hrs. }\end{array}$ & $\begin{array}{l}\text { Arrive via PK267 } \\
\text { Check in Hotel }\end{array}$ \\
\hline & $\begin{array}{l}1100 \text { hrs. }-1230 \text { hrs. } \\
1330 \text { hrs. }-11430 \text { hrs. } \\
1500 \text { hrs. - } 1530 \text { hrs. } \\
1530 \text { hrs. }-1630 \text { hrs. }\end{array}$ & $\begin{array}{l}\text { - Health and Population Services in Bangladesh: } \\
\text { An Overview } \\
\text { Dr. Ubaidur Rob and Noorunnabi Talukder } \\
\text { - Introduction on Emergency Contraception } \\
\text { Dr. Sharif Md. Ismail Hossain } \\
\text { - Introducing ECP in the National Family Planning } \\
\text { Program, Lessons learnt } \\
\text { Dr. M.E. Khan } \\
\text { Meeting with Secretary, Ministry of Health and Family } \\
\text { Welfare, Government of the People's Republic of } \\
\text { Bangladesh } \\
\text { Lunch } \\
\text { Meeting with Ms. Tahera Ahmed, Assistant } \\
\text { Representative, UNFPA }\end{array}$ \\
\hline $\begin{array}{l}03.12 .07 \\
\text { Monday }\end{array}$ & $\begin{array}{l}1000 \text { hrs. }-1200 \text { hrs. } \\
1230 \text { hrs. - } 1400 \text { hrs. } \\
1400 \text { hrs onwards }\end{array}$ & $\begin{array}{l}\text { Meeting with Director General, Directorate General of } \\
\text { Family Planning and Director (MCH-Services) and Line } \\
\text { Director (MC-RH), DGFP at Azimpur } \\
\text { Lunch (on the way) } \\
\text { Free time }\end{array}$ \\
\hline $\begin{array}{l}04.12 .07 \\
\text { Tuesday }\end{array}$ & 0800 hrs. -1600 hrs. & $\begin{array}{l}\text { Field visit to GOB facilities at Gazipur (Konabari HFWC } \\
\text { and Kaliakuir Upazila Health Complex) and JTS NGO } \\
\text { clinic at Sreepur (Rural Clinic) }\end{array}$ \\
\hline 05.12 .07 & $\begin{array}{l}0930 \text { hrs. }-1200 \text { hrs. } \\
1300 \text { hrs. }-1400 \text { hrs. } \\
1500 \text { hrs. }-1630 \text { hrs. } \\
1900 \text { hrs. }\end{array}$ & $\begin{array}{l}\text { Meeting with NGO officials at PSTC office ( PSTC, } \\
\text { CWFD, MSCS, FPAB, NSDP, Chemonics, Swanirwar } \\
\text { Bangladesh and JTS) and visit PSTC clinic at Rampura } \\
\text { (Urban Clinic) } \\
\text { Lunch } \\
\text { Debriefing at PC office } \\
\text { Reception at Batong Rouge, Road - 103, Gulshan } 2\end{array}$ \\
\hline $\begin{array}{l}06.12 .07 \\
\text { Thursday }\end{array}$ & 1100 hrs. & Departure \\
\hline
\end{tabular}




\section{Appendix 2: List of Selected Participants in the EC Seminar}

1. Dr. A.J Khan, Minster Population Welfare, Government of Pakistan

2. Mr. Ejaz Rahim, Minister of Health, Government of Pakistan

3. Dr. Mohammad Sharif, Secretary Ministry of Population Welfare, Government of Pakistan

4. Secretary, Ministry of Heath, Government of Pakistan

5. Dr. Mumtaz Esker, DG Technical, Ministry of Population Welfare, Government of Pakistan

6. Dr. Assad Hafeez, National Coordinator FP\&PHC

7. Ms. Mary Skarie, Health Officer, Director, USAID

8. Dr. Frances Donnay - Representative, UNFPA

9. Dr. Zeba Sathar, Country Director, Population Council Pakistan

10. Ms. Shahida Azfar, Chief of Party FALAH Project

11. Dr. M.E Khan, Regional Associate Director and Senior Associate, FRONTIERS Program, Population Council, India

12. Dr. Ubaidur Rob, Country Director, Population Council Bangladesh

13. Dr. Sharif Mohammed Ismail Hossain, Senior Program Officer, FRONTIERS Program, Population Council, Bangladesh

14. Dr. Jahiruddin Ahmed, Dy Director General, Family Planning Association, Bangladesh

15. Dr Gul Rashida, Population Council, Pakistan

16. Dr Mir Ali, Population Council, Pakistan

17. Dr. Maheen Malik, Greenstar Social Marketing

18. Dr. Farooq Ahmed, Psychiatrist, Religious Scholar.

* This list does not include about 60 Federal, Provincial and Training Institute officials who participated in the consultation and about 10 Population Council staff who were directly involved in the organizing the consultation. 


\section{Appendix 3: Agenda of Two-day National Consultative Seminar on Emergency Contraception}

January 22-23 2008 at Marriot Hotel, Islamabad

\begin{tabular}{|c|c|}
\hline \multicolumn{2}{|c|}{ Day 1 (Tuesday) - January 22, 2008} \\
\hline 09:30 - 09:35 & Recitation from the Holy Quran \\
\hline 09:35 - 09:40 & Welcome remarks by Ms. Shahida Azfar, Chief of Party, FALAH Project \\
\hline 09:40 - 09:45 & Remarks by Mary Skarie, Health Officer, USAID \\
\hline $09: 45-09: 55$ & $\begin{array}{l}\text { An Introduction to Emergency Contraception by Dr. Asad Hafeez, National Coordinator } \\
\text { for Family Planning and Primary Health Care }\end{array}$ \\
\hline $09: 55-10: 15$ & $\begin{array}{l}\text { Introducing Emergency Contraception within in Public Health System in Bangladesh by } \\
\text { Dr Muhammad Sharif Ismail (PC) B.D. }\end{array}$ \\
\hline $10: 15-10: 30$ & How to reach communities - Lessons learnt from the region by Dr. M.E. Khan \\
\hline $10: 30-10: 40$ & Current Status of EC in Pakistan by Dr. Mumtaz Esker, DG(T), MoPW Pakistan \\
\hline $10: 40-10: 50$ & Social marketing of ECP by Dr. Maheen from Greenstar \\
\hline $10: 50-11: 00$ & Comments by Dr. Farooq Ahmed religious scholar \\
\hline $11: 00-11: 15$ & Remarks by Chief Guest, Prof. A.J. Khan, Minister of Population Welfare \\
\hline $11: 15-11: 20$ & $\begin{array}{l}\text { Vote of Thanks of Dr. Malik Safi (Deputy National Coordinator), National Programme for } \\
\text { Family Planning and Primary Health Care }\end{array}$ \\
\hline $11: 20-11: 35$ & Tea Break \\
\hline $11: 35-01: 30$ & $\begin{array}{l}\text { Panel Discussion - Utilizing the community based network for delivery of Emergency } \\
\text { Contraceptive pills (Chair - Ms Shahida Azfar) } \\
\text { Dr. Mumtaz Esker - Experience and learning } \\
\text { Dr. Assad Hafeez - Advantage, possible challenges and possibility of phased manner } \\
\quad \text { implementation. } \\
\text { Dr.Jaheer Uddin - Operational and administrative challenges. } \\
\text { Dr. Ubaidur Rob - Lessons learned from other countries. Feasibility of provision of } \\
\text { EC through paramedics. } \\
\text { Dr. Ghazala Mehmood - Medical Aspects of EC }\end{array}$ \\
\hline $01: 30-02: 30$ & Lunch \\
\hline 02:30- 04:00 & $\begin{array}{l}\text { Group Work Implementing the EC Program in Pakistan: (Session Chair - Dr. Mumtaz } \\
\text { Esker (DG MoPW) } \\
\text { - Modalities for provision of ECP through community based providers of MoH } \\
\text { (Policy, Training and Logistics). Rapporteur - Dr Malik Safi } \\
\text { - Modalities for provision of ECP through static public health facilities (Policy, } \\
\text { Training and Logistics). Rapporteur - }\end{array}$ \\
\hline
\end{tabular}




\begin{tabular}{|c|c|}
\hline \multicolumn{2}{|c|}{ Day 2 (Wednesday) - January 23, 2008} \\
\hline 09:30 - 10:30 & Group Work Continued \\
\hline $10: 30-11: 30$ & Group Presentations \\
\hline $11: 30-11: 45$ & Finalization of Recommendations \\
\hline $11: 45-12: 00$ & Tea Break \\
\hline \multicolumn{2}{|c|}{$\begin{array}{ll}\text { Closing Session } \\
\text { Chair: } & \text { Mr Ejaz Rahim, Minister for Health } \\
\text { Co-chair: } & \text { Major General Shahida Malik, DG Health }\end{array}$} \\
\hline $12: 00-12: 05$ & Recitation from the Holy Quran \\
\hline $12: 05-12: 015$ & Welcome by Dr Zeba A Sathar \\
\hline $12: 15-12: 55$ & Presentation of Consolidated group presentation by Dr. Asad Hafeez \\
\hline $12: 55-01: 20$ & Concluding remarks by the chief guest, Mr Ejaz Rahim, Minister for Health \\
\hline $01: 20-01: 30$ & Vote of Thanks by Ms Shahida Azfar \\
\hline $01: 30-02: 30$ & Lunch \\
\hline Close & Seminar \\
\hline
\end{tabular}




\section{Appendix 4: Outcomes of Group Work on Implementing the Emergency Contraception Program in Pakistan}

Group 1: Modalities for provision of ECP through community based providers of MOH

\begin{tabular}{|c|c|c|c|c|}
\hline Strategy & Activities & \multicolumn{3}{|c|}{ Recommendations } \\
\hline Policy Decision & $\begin{array}{l}\text { 1: Brand Name } \\
\text { 2: TCI- LHW } \\
\text { 3: Approval by MOH } \\
\text { 4: Phasing / Piloting } \\
\text { 5: Evaluation } \\
\text { 6: PC-1 Inclusion }\end{array}$ & \multicolumn{3}{|c|}{$\begin{array}{l}\text { 1. BRAND NAME } \\
\text { (EC Pills) } \\
\text { 2. Approval by TCI-LHW (Start of February 2008) } \\
\text { Joint proposal for TSI in March } 2008 \text { will be prepared } \\
\text { by Population Council , MOPW and MOH. } \\
\text { 3. Approval by MOH (March 2008) } \\
\text { 4. Phasing - } 1 \text { (piloting) } \\
02 \text { Districts from each province (FALAH Districts) } \\
\text { - NWFP - Buner \& Charsadda } \\
\text { - Sindh - Ghotki \& Thatta } \\
\text { - Balochistan - Gwadar \& Zhob } \\
\text { - Punjab - Jhelum and D.G Khan } \\
\text { 5. Evaluation will be done after } 1 \text { year for community } \\
\text { acceptability and consumption pattern. Evaluation } \\
\text { cost will be borne by FALAH Project. } \\
\text { 6. PC-1 will be based on TCI and evaluation of the } \\
\text { pilot phase } 1 \text {. }\end{array}$} \\
\hline Logistics & $\begin{array}{l}\text { 1: For LHW at community } \\
\text { level } \\
\text { 2: Cost } \\
\text { 3: Inclusion of supplies in } \\
\text { PC-1 } \\
\text { 4: Social, marketing Partnership }\end{array}$ & \multicolumn{3}{|c|}{$\begin{array}{l}\text { 1. Logistic channel of national program of MOH will } \\
\text { be followed. The supplies will be either from } \\
\text { MOPW/UNFPA (FALAH will facilitate for provision). } \\
\text { Logistic calculation for LHWs: } \\
\mathbf{1}^{\text {st }} \text { supply } \mathbf{4 0} \% \text { (CPR) }+\mathbf{1 0 \%} \text { extra. } \\
\text { All clients of family planning users will be provided } \\
\text { EC Pills. } \\
\text { All Elcos who are not using FP method. } \\
\text { 2. It should be provided free of cost by LHWs } \\
\text { 3. After evaluation it will be included } \\
\text { 4. Not required at this stage. }\end{array}$} \\
\hline \multirow[t]{4}{*}{ Trainings } & \multirow[t]{4}{*}{$\begin{array}{l}\text { 1: LHWs / LHVs / LHW } \\
\text { Supervisors }\end{array}$} & \multicolumn{3}{|c|}{$\begin{array}{l}\text { 1. Training cascade of National program will be } \\
\text { followed. } \\
\text { Provincial tier not } \\
\text { required }\end{array}$} \\
\hline & & National level workshop & $\longrightarrow$ & $\begin{array}{l}\text { District Master Trainers + } \\
\text { PPIU Rep. }\end{array}$ \\
\hline & & District level workshop & & Facility Master trainers \\
\hline & & Facility level workshop & $\longrightarrow$ & LHWS \\
\hline
\end{tabular}




\begin{tabular}{|c|c|c|}
\hline Strategy & Activities & Recommendations \\
\hline & $\begin{array}{l}\text { 2: Material / Manuals } \\
\\
\text { 3: Training Process } \\
\text { - Federal } \\
\text { - Province Districts } \\
\text { - FLCF }\end{array}$ & $\begin{array}{l}\text { 2. The Training material from Bangladesh will be } \\
\text { adopted and modified according to our scenario. The } \\
\text { training material will be finalized (developed) in } \\
\text { concurrence with provinces and MOPW. } \\
\text { (Tailor made training material manuals of } \\
\text { Bangladesh and MOPW and other partners would be } \\
\text { reviewed for adoption) } \\
\text { Time Period: } \\
\text { - Development of material and Translation - } \\
\text { By May } 2008 \\
\text { - Implementation - } 1^{\text {st }} \text { quarter of FY July - } \\
\quad \text { Aug 2008-09 } \\
\text { 3. Training at all levels to be jointly organized by } \\
\text { MOH and MOPW in collaboration with FALAH project } \\
\text { (cost of trainings) } \\
\text { Printing cost will be borne by FALAH project. }\end{array}$ \\
\hline Advocacy & $\begin{array}{l}\text { IEC } \\
\text { 1: Whom to reach } \\
\text { 2: How to reach }\end{array}$ & $\begin{array}{l}\text { 1: Advocacy Seminars } \\
\text { For Provincial and District Health Managers } \\
\text { Political leaders - District Nazims, donor and partner } \\
\text { agencies, service providers and stake holders from } \\
\text { public and private sectors including line ministries. } \\
\text { One Orientation seminar in each province and } \\
\text { district level. } \\
\text { 2: Social Mobilization } \\
\text { IPC, posters, brochures, TV talk shows, local radio } \\
\text { channels. } \\
\text { Material required will be modified / adopted from } \\
\text { Bangladesh and MOPW and further translated into } \\
\text { local regional language in consultation with provinces } \\
\text { and MOPW. }\end{array}$ \\
\hline
\end{tabular}

Group 2: Modalities for Provision of ECP through Static Public Health Facilities

\begin{tabular}{|c|c|c|}
\hline Strategies & Activities & Recommendations \\
\hline Policy Decision & $\begin{array}{l}\text { 1. Approval by MOH for EC at } \\
\text { First Level Care Facility } \\
\text { 2. Phasing } \\
\text { 3. Evaluation after } 6 \text {-months/ } 1 \\
\text { year } \\
\text { 4. Expansion to second phase }\end{array}$ & $\begin{array}{l}\text { 1-2. } 20 \text { FALAH districts + additional districts where } \\
\text { there are conditionally available resources. } \\
\text { Districts: } \\
\text { NWFP: Charsadda, Battagram, Buner, Upper Dir, } \\
\text { Lakki Marwat, Swat. } \\
\text { Balochistan: Khuzdar, Zhob, Kech, Gwadar, } \\
\text { Jaffarabad, Lasbela } \\
\text { Sindh: Dadu, Ghotki, Thatta, Sanghar, Sukkur, } \\
\text { Larkana } \\
\text { Punjab: Jhelum, DG Khan } \\
\text { NON-FALAH Districts } \\
\text { - NWFP: Karak, Swabi, Mardan } \\
\text { - Balochistan: Loralai, Pashin } \\
\text { - AJK: Bagh } \\
\text { - FANA: Gilgit } \\
\text { - FATA: Khyber Agency }\end{array}$ \\
\hline
\end{tabular}




\begin{tabular}{|c|c|c|}
\hline Strategies & Activities & Recommendations \\
\hline & & $\begin{array}{l}\text { Responsibility at the District Level: EDO Health } \\
\text { /MNCH } \\
\text { } \rightarrow \text { DG Health MoH will issue notification to PDGs } \\
\text { dept of Health and provincial health departments will } \\
\text { write to district health departments for } \\
\text { implementation of ECP in their respective districts. } \\
\text { Selection Criteria for Master Trainers: } \\
\text { - Experienced trainer } \\
\text { - Posted in DHDC will be preferred } \\
\text { 3. Minimum } 1 \text { year needed for evaluation: } \\
\text { Process Indicators: } \\
\text { - Number of providers trained } \\
\text { - Male/ female doctors } \\
\text { - Paramedics/ Nurses/ LHVs } \\
\text { - Dispenser/Compounder } \\
\text { - Tool to assess training: Pre and Post Tests } \\
\text { - Availability of IEC material at the outlet level } \\
\text { - } \quad \text { Dispecially in Urdu and Sindhi languages. } \\
\text { or any such visible and accessible area. Also } \\
\quad \text { in LHV and female staff room } \\
\text { - Availability of flipcharts as counseling tool } \\
\text { - Distribution of material to visiting clients } \\
\text { - Supply of ECP on the date of visit } \\
\text { - Monthly distribution of ECP } \\
\text { - Quality of counseling (integration with } \\
\text { - Integration with routine MIS; quality of } \\
\text { - Fegistration of FP clients including ECP } \\
\text { 1. Follow up sample survey of the providers after } 4 \\
\text { months to assess continuation } \\
\text { 2. Rapid community appraisal required }\end{array}$ \\
\hline Logistics & $\begin{array}{l}\text { DoH Procurement of } \\
\text { Contraceptives including ECP } \\
\text { for FLCF from MoPW/ Social } \\
\text { Marketing Organization on } \\
\text { Purchase by Health Department }\end{array}$ & $\begin{array}{l}\text { MoPW will procure the ECP and distribute to all the } \\
\text { health facilities along with other contraceptive } \\
\text { supplies. } \\
\text {-Approximate required ECP: Estimated } 10,000 \mathrm{ECP} \\
\text { Packets per district initially, and then depending on } \\
\text { consumption. }\end{array}$ \\
\hline Trainings & $\begin{array}{l}\text { 1. FLCF staff (LHV, WMO, MO) } \\
\text { 2. Who will train } \\
\text { 3. Training materials } \\
\text { 4. When to train, where }\end{array}$ & $\begin{array}{l}\text { 1. } 6 \text { master trainers from each district will be } \\
\text { trained at the provincial level. These trainers } \\
\text { will provide training at the district level. } \\
\text { 2. Master Trainers will be trained by PC and } \\
\text { JHPIEGO } \\
\text { 3. Training materials to be taken from } \\
\text { Population Council regional office, to be } \\
\text { modified by FALAH for Pakistani context in } \\
\text { Urdu and Sindhi. } \\
\text { 4. Training to be completed in May and June. }\end{array}$ \\
\hline Advocacy & & $\begin{array}{l}\text { Clients coming to facilities, (all eligible women and } \\
\text { couples) will be provided printed IEC materials and } \\
\text { interpersonal counseling. }\end{array}$ \\
\hline
\end{tabular}

